\title{
Catch and Release DNA Decoys: Capture and Photochemical Dissociation of NF- $x$ B Transcription Factors
}

\author{
Nicholas B. Struntz and Daniel A. Harki ${ }^{*}$ \\ Department of Medicinal Chemistry, University of Minnesota, 2231 6th Street S.E., Minneapolis, \\ MN, 55455, USA
}

\begin{abstract}
Catch and Release DNA Decoys (CRDDs) are a new class of non-natural DNA probes that capture and dissociate from DNA-binding proteins using a light trigger. Photolytic cleavage of non-natural nucleobases in the CRDD yields abasic sites and truncation products that lower the affinity of the CRDD for its protein target. Herein, we demonstrate the ability of the first-generation CRDD to bind and release NF- $\kappa$ B proteins. This platform technology should be applicable to other DNAbinding proteins by modification of the target sequence.
\end{abstract}

\section{Graphical Abstract}

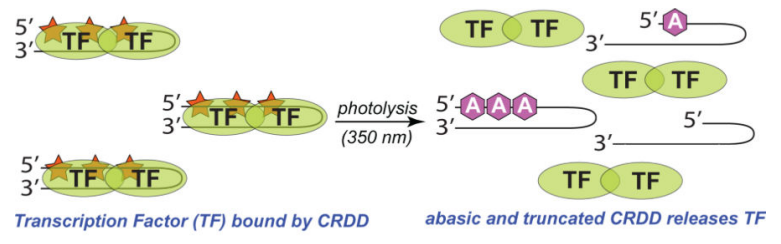

$\widehat{\imath}$-depurination monomer A- abasic site

DNA decoys modulate cellular and viral transcription by sequestering regulatory proteins, both activators and repressors, from their endogenous DNA binding sites, thereby altering gene expression. ${ }^{1-3}$ Transcription factors (TF) such as NF- $\mathrm{kB},{ }^{4-7} \mathrm{AP}-1,{ }^{8}$ STAT $3,{ }^{9}$ and HNF4-1/MAZ-1 ${ }^{10}$ have been successfully targeted by sequence-specific DNA decoys and these reagents have demonstrated utility in both cell culture and animal models of disease. Consequently, DNA decoys constitute powerful tool compounds for mechanistic biochemical studies and promising therapeutic agents for regulating aberrant transcription factor activities.

The utilization of light as a bio-orthogonal trigger to regulate the activities of biologically active molecules has garnered substantial attention in recent years. ${ }^{11,12}$ Incorporation of nitrobenzyl derivatives onto nucleobases of DNA and RNA oligonucleotides, which sterically block binding to cognate proteins or nucleic acids, have yielded an arsenal of

*Corresponding Author daharki@umn.edu. ASSOCIATED CONTENT

Supplemental Figures 1-5, Supplemental Table 1, and LC-MS chromatographs of 4-14. This material is available free of charge via the Internet at http://pubs.acs.org. 
caged reagents with broad utilities in transcriptional and translational regulation. ${ }^{7,13}$ A caged DNA decoy targeting NF- $\kappa$ B proteins has been developed, which enables light-mediated spatiotemporal control of expression of NF- $\kappa$ B-target genes. ${ }^{14}$ This 'off-to-on' DNA decoy is activated by photolysis of the appended caging groups, which reveals an exogenous DNA hairpin that sequesters NF- $\kappa \mathrm{B}$ proteins.

We report a novel class of DNA decoys, termed 'Catch and Release DNA Decoys (CRDDs)', that capture and release DNA-binding proteins using a light trigger (Fig. 1a). Unlike caged DNA decoys, CRDDs are an 'on-to-off' platform that utilizes light to promote photochemical destruction of the DNA decoy and dissociation of the protein-DNA complex. Our design utilizes depurination-competent ${ }^{15}$ mimics of natural nucleobases that when incorporated into a DNA decoy function as natural nucleobases and enable decoy binding to its designed protein target. However, CRDD photolysis results in formation of multiple abasic sites within the decoy, as well as truncated decoys resulting from $\beta$ - and $\delta$-elimination at abasic sites, yielding a modified CRDD that possesses significantly diminished affinity for its design protein target. Consequently, CRDD photolysis enables release of the sequestered protein target. Here, we report our first-generation CRDD that can capture and release NF$\kappa \mathrm{B}$ proteins.

\section{RESULTS AND DISCUSSION}

\section{Design of CRDDs Targeting NF- $\times B$ Transcription Factors}

Incorporation of 2-nitrobenzylethers in place of native nucleobases in DNA oligonucleotides has been utilized as a strategy to generate abasic sites photochemically with sequence specificity. ${ }^{16-18}$ Additionally, 7-nitroindole (1) has been shown to photochemically depurinate in DNA oligonucleotides, yielding a 2'-deoxyribolactone (2) abasic site in DNA (mechanism: Supplemental Fig. 1), which can undergo $\beta$ - and $\delta$-elimination resulting in strand cleavage, and a 7-nitrosoindole (3) by-product (Fig 1b). ${ }^{19-21}$ Given the obvious structural similarities between indole heterocycles and purine nucleobases, which is further reinforced by work demonstrating that 5-nitroindole can serve as a 'universal base' in DNA $^{22}$ and that both 5- and 7-nitroindole nucleobases can be enzymatically recognized by Klenow fragment DNA polymerase I, ${ }^{23}$ we hypothesized that 7-nitroindole may suitably mimic natural purines in established DNA decoys that bind NF- $\kappa$ B proteins. Furthermore, we hypothesized that photolysis of the NF- $\kappa \mathrm{B}$-decoy complex would enable protein release through photochemical destruction of the decoy as previously described (Fig 1c).

The NF- $\kappa \mathrm{B}$ signaling pathway regulates scores of cellular processes associated with inflammation, cell survival and proliferation, and aberrant $\mathrm{NF}-\kappa \mathrm{B}$ activity is frequently found in cancer, cardiovascular disease, and autoimmune diseases. ${ }^{24}$ Given the fundamental role of NF- $\kappa \mathrm{B}$ signaling in many human diseases, as well as strong precedence for the development of NF- $\kappa$ B-targeted DNA decoys, ${ }^{4-7}$ including caged reagents, ${ }^{14}$ we developed our first CRDD against NF- $\kappa \mathrm{B}$ proteins. The four purine site of the $\mathrm{NF}-\kappa \mathrm{B}$ consensus sequence (5'-GGGRNYYYCC-3', where $\mathrm{R}$ is a purine, $\mathrm{Y}$ is a pyrimidine, and $\mathrm{N}$ is any nucleotide) is crucial for DNA binding of p50. ${ }^{25}$ Therefore, we utilized established NF- $\kappa \mathrm{B}$ decoy $4^{14}$ as our base hairpin sequence for optimizing NF- $\kappa$ B-targeted CRDDs (Fig 2a). One-to-three purines included in or flanking the 4-G site were replaced with 7-NI 
nucleotides, yielding CRDDs 5, 7, and $\mathbf{9}$. The substitutions of the 7-NIs were also placed in succession to amplify the result of multiple depurination events in a concentrated area. These decoys were synthesized using the known 7-NI phosphoramidite ${ }^{20}$ under standard solid-phase DNA synthesis conditions. Photolysis of 5, 7, and $\mathbf{9}$ followed by purification afforded decoys $\mathbf{6}, \mathbf{8}$, and $\mathbf{1 0}$ containing one, two, and three abasic sites, respectively. A control scrambled DNA decoy 11, a scrambled CRDD 12 containing three 7-NI nucleotides, and DNA decoy 13 with three base pair mismatches in place of the three 7-NI nucleotides were also synthesized.

\section{Thermal Stability of DNA Decoys}

The thermal stability of DNA duplexes and hairpins containing the 7-NI nucleobase was studied by UV thermal melting experiments. ${ }^{26}$ First, 7-NI was singly incorporated into oligonucleotide 14 and thermal melting of duplex DNA containing all natural nucleotides hybridized to 7-NI was measured. In addition, the DNA stability of duplexes containing guanine and 5-nitroindole nucleobases was included for comparison (Supplementary Table 1). ${ }^{2226}$ In comparison to G-C pairing, incorporation of 5-nitroindole into duplex DNA in place of guanine decreases stability $\left(\Delta \mathrm{T}_{\mathrm{m}}=-7.5^{\circ} \mathrm{C}\right)$, while 7-nitroindole is more destabilizing $\left(\Delta \mathrm{T}_{\mathrm{m}}=-15.2^{\circ} \mathrm{C}\right)$. Thermal melting of CRDDs $\mathbf{5}, \mathbf{7}$, and $\mathbf{9}$ and the stability of their corresponding abasic photo-products $\mathbf{6 , 8}, \mathbf{8}$ and $\mathbf{1 0}$ were then performed (Fig. 2b). The introduction of a single 7-NI nucleotide into CCRD 5 decreased duplex stability as expected $\left(\Delta \mathrm{T}_{\mathrm{m}}=-4.1^{\circ} \mathrm{C}\right)$, but photochemical introduction of the abasic site, yielding $\mathbf{6}$, increased stability compared to $\mathbf{5}\left(\Delta \Delta \mathrm{T}_{\mathrm{m}}=+2.6^{\circ} \mathrm{C}\right)$. From this result, it was hypothesized that more than one abasic site would be needed to sufficiently disrupt duplex formation and overall binding affinity after depurination. The thermal stabilities of $\mathbf{7}$ and $\mathbf{9}$ were lower in comparison to non-modified decoy $4\left(\Delta \mathrm{T}_{\mathrm{m}}=-10.3{ }^{\circ} \mathrm{C}\right.$ and $-12.2^{\circ} \mathrm{C}$, respectively), yet both are sufficiently stable $\left(\mathrm{T}_{\mathrm{m}}=72.3{ }^{\circ} \mathrm{C}\right.$ and $70.4{ }^{\circ} \mathrm{C}$, respectively). As anticipated, photochemical introduction of multiple abasic sites forming $\mathbf{8}$ (two abasic sites) is destabilizing to duplex DNA $\left(\Delta \mathrm{T}_{\mathrm{m}}=-12.3{ }^{\circ} \mathrm{C}\right.$ compared to $4 ; \Delta \mathrm{T}_{\mathrm{m}}=-2.0^{\circ} \mathrm{C}$ compared to 7) and even greater for $10,\left(\Delta \mathrm{T}_{\mathrm{m}}=-15.8^{\circ} \mathrm{C}\right.$ compared to $4 ; \Delta \mathrm{T}_{\mathrm{m}}=-3.6^{\circ} \mathrm{C}$ compared to 9$)$, which contains three abasic sites. The thermal stability of scramble 12 containing three 7NIs was lower in comparison to non-modified scramble decoy $\mathbf{1 1}\left(\Delta \mathrm{T}_{\mathrm{m}}=-12.4{ }^{\circ} \mathrm{C}\right)$, which is similar to that previously seen with CRDD 9 in comparison to 4 . The DNA decoy with three base pair mismatches $\mathbf{1 3}$ in place of the three 7-NI nucleotides also displayed a lowered $\mathrm{T}_{\mathrm{m}}$ compared to native $\mathbf{4}\left(\Delta \mathrm{T}_{\mathrm{m}}=-10.4{ }^{\circ} \mathrm{C}\right)$.

\section{Electrophoretic Mobility Shift Assays of NF-xB-DNA Complexes}

We next evaluated the ability of the decoys to capture NF- $\kappa \mathrm{B}$ proteins by electrophoretic mobility shift assays (EMSAs). ${ }^{32} \mathrm{P}$-end-labeled 4-13 were added to a solution of recombinant $\mathrm{p} 50-\mathrm{p} 65$ proteins and protein binding was measured. The NF- $\kappa \mathrm{B}$ directed DNA decoys exhibited specific binding toward NF- $\kappa$ B proteins, as little observable binding occurred with scramble and base pair mismatch decoys 11-13 (Supplemental Fig. 2). To characterize the NF- $\kappa \mathrm{B}$ complexes responsible for binding to DNA decoys, supershifting EMSAs were carried out (Supplemental Fig. 3). The p50 utilized in all experiments is a partially truncated recombinant protein (35-381; 433 amino acids for wild-type enzyme). 
The p65 recombinant protein utilized in these experiments is primarily the DNA-binding domain with a N-terminal GST tag (1-306; 551 amino acids for wild-type enzyme). Addition of p50 antibody to NF- $\mathrm{BB}-4$ complexes completely supershifted the band, indicating that p50 protein is present in all complexes bound to 4 (Supplemental Fig. 3a). However, addition of p65 antibody only partially supershifted the NF- $\kappa \mathrm{B}$ complex (Supplemental Fig. 3a). These data suggest that the observed NF- $\kappa B-4$ complex is comprised of both p50-p65 heterodimers (supershift with p65 antibody) and p50-p50 homodimers (no supershift with p65 antibody), which is consistent with previous studies. ${ }^{27}$ The supershift experiment was repeated with a near full-length p65 recombinant protein (1-537), which confirmed these results (Supplemental Fig. 3b). The ability of CRDD 9 (containing three 7-NIs) to bind the NF- $\kappa \mathrm{B}$ complexes was similarly confirmed by EMSA supershift analysis (Supplemental Fig. 3c) To support these EMSA results, we performed quantitative EMSA titrations with NF- $\kappa \mathrm{B}$ proteins to obtain equilibrium dissociation constants for all three possible NF- $\kappa$ B complexes with native DNA decoy 4 (Fig. 3). The p50-p65 heterodimer demonstrated the highest binding affinity $\left(K_{\mathrm{d}}=15.3 \mathrm{nM}\right)$. The $\mathrm{p} 50$ and p65 homodimer proteins were also measured ( $K_{\mathrm{d}}=31.1 \mathrm{nM}$ and $91.7 \mathrm{nM}$, respectively), revealing the p65 homodimer has a 6-fold lower binding affinity for 4 than the p50-p65 heterodimer, which is consistent with a previous study. ${ }^{28}$ Therefore, our studies of CRDD binding to NF- $\kappa$ B proteins are sampling a mixture of both $\mathrm{p} 50$ and $\mathrm{p} 65$ heterodimers and homodimers.

As shown in Fig. 4a, CRDDs 5, 7, and 9 demonstrated the ability to bind the NF- $\kappa$ B complex similarly to native decoy 4 . Quantitative analysis using densitometry revealed an approximately $50 \%$ decrease in signal of CRDD 9 compared to native 4 . Decoys 6 and 8 , however, retain the ability to bind despite containing one and two abasic sites. Decoy $\mathbf{1 0}$, containing three abasic sites, demonstrated no observable complex formation upon addition of proteins. This result revealed that the photochemical transformation of $\mathbf{9}$ to $\mathbf{1 0}$ abolishes NF- $\kappa B$ binding, and therefore, we utilized this compound for further studies.

To corroborate our EMSA results, we performed quantitative EMSA titrations with NF- $\kappa B$ proteins and 4, 9, and 10 to obtain equilibrium dissociation constants for our probes. DNA decoy $4\left(K_{\mathrm{d}}=15.3 \mathrm{nM}\right)$ and CRDD $9\left(K_{\mathrm{d}}=36.2 \mathrm{nM}\right)$ exhibited comparable binding affinities for NF- $\kappa$ B proteins (Fig. 4b). Remarkably, CRDD 10, which contains three abasic sites in the p50 recognition domain, exhibited no observable binding to the NF- $\kappa B$ proteins $\left(K_{\mathrm{d}}>500 \mathrm{nM}\right)$. These data further support our model by which CRDD depurination ablates protein recognition.

\section{Characterization of CRDD Photo-products}

To characterize the kinetics and the identities of the photo-products resulting from irradiation of $\mathbf{9}$, we utilized liquid chromatography-mass spectrometry (LC-MS) analysis of an irradiated aqueous sample. As shown in Fig. $\mathbf{4 c}$, irradiation of $\mathbf{9}$ yielded fast photolysis $\left(\mathrm{t}_{1 / 2}=1.2 \mathrm{~min} ; 350 \mathrm{~nm}\right.$ light; light intensity: $5.66 \times 10^{-8}$ ein $\left.\mathrm{cm}^{-2} \mathrm{~s}^{-1}\right)$ whereby $90 \%$ of $\mathbf{9}$ was converted to photo-products within 4.5 minutes. The quantum yield $(\Phi)$ of 9 was determined to be 0.0104 , which is comparable, albeit lower, than 6-nitropiperonyloxymethyl (NPOM)protected thymine $(\Phi=0.094) .{ }^{29}$ After 25 minutes of irradiation of CRDD 9, very little 
decoy remained and multiple abasic decoys and truncation products resulting from $\beta$ - and $\delta$ elimination were detected (Fig. 4d). As expected, formation of decoys with one abasic site increases immediately, peaks around 5 minutes, and decreases as multiple abasic sites are formed. Decoys with one, two, and three abasic sites $(\mathbf{1 4}, \mathbf{1 5}$, and 10, respectively) were observed after 25 minutes of irradiation. These abasic decoys result in approximately $65 \%$ of the total number of photo-products formed (Fig. 4d, dashed lines). Several truncated products (16-19) are formed by $\beta$ and $\delta$-eliminations of the 3' and 5' phosphates, due to the instability of the abasic lactones within DNA. ${ }^{21}$ Of these truncated products, 2-6 nucleotides are cleaved from the 5'-end of the decoy (Fig. 4d, solid lines). Consequently, photolysis of 9 results in substantial modification to the essential 4-G NF- $\kappa$ B binding site, which disrupts protein-CRDD binding.

\section{Catch and Release of NF- $x$ B Proteins}

To assess the ability of CRDD 9 to release the NF- $\kappa B$ complex photochemically, a solution of ${ }^{32} \mathrm{P}$-labeled 9 and recombinant proteins were incubated in binding buffer, followed by treatment with $350 \mathrm{~nm}$ light. Photolysis of the 9-NF- $\kappa \mathrm{B}$ complex, over time, drives release of the transcription factors upon formation of abasic sites and truncated products of the DNA decoy (Fig. 5a). After 4 minutes of irradiation of the 9-NF- $\kappa$ B complex, approximately 50\% of the NF- $\kappa$ B proteins are released even through the protein is in large excess (Fig. 5b). Recovery of the complex can be obtained by additional ${ }^{32} \mathrm{P}$-labeled $\mathbf{9}$, demonstrating the viability of NF- $\kappa B$ proteins to bind DNA after irradiation with light. Additionally, western blot and EMSA analysis of p50 and p65 proteins following subjection to the photolysis conditions ( $350 \mathrm{~nm}$ light, in $\mathrm{H}_{2} \mathrm{O}$ ) reveals no apparent damage to proteins (Supplemental

Fig. 5).

\section{CONCLUSIONS}

We demonstrate for the first time the capture and photochemical release of transcription factors using a novel photo-responsive Catch and Release DNA Decoy (CRDD). Photolysis of CRDD 9 resulted in formation of abasic sites and truncated products abolishing affinity for binding to NF- $\kappa \mathrm{B}$ proteins. These results have demonstrated that CRDDs can be used to effectively capture and spatiotemporally release TFs, which complement existing caged DNA decoys. The utilization of this technology in cell culture, as well as the development of second-generation depurination monomers and new applications, will be reported in due course.

\section{METHODS}

\section{Solid Phase DNA Synthesis}

Oligonucleotides were synthesized using standard solid-phase phosphoramidite chemistry on an Applied Biosystems 394 DNA/RNA synthesizer. ${ }^{30}$ 7-Nitroindole (7-NI) phosphoramidite was synthesized as previously described. ${ }^{2031}$ All other phosphoramidites, solvents, and solid supports $(1.0 \mu \mathrm{mol})$ were purchased from Glen Research Corporation. 7NI was incorporated into the oligonucleotide by a manual coupling, whereas all other nucleotides were incorporated with automated couplings. Automated DNA synthesis was 
paused immediately prior to incorporation of 7-NI and the solid support was removed from the synthesizer. To achieve a manual coupling, 7-NI phosphoramidite $(15 \mathrm{mg})$ was dissolved in anhydrous $\mathrm{MeCN}(200 \mu \mathrm{L})$, loaded into a syringe $(1 \mathrm{~mL})$, and attached to one side of the solid support. A second syringe $(1 \mathrm{~mL})$ was loaded with Activator $(600 \mu \mathrm{L}$, Glen Research Corp.) and attached to the other end of the solid support. The solutions were then mixed through the solid support vessel manually by the two syringes for $20 \mathrm{~min}$. Afterwards, the solid support vessel was drained, washed with anhydrous $\mathrm{MeCN}(1 \mathrm{~mL})$ and returned to the synthesizer. This procedure for manual coupling was performed for all 7-NI incorporations. Following the synthesis, the resin was transferred to a fritted reaction vessel. Concentrated aqueous ammonium hydroxide $(2.5 \mathrm{~mL})$ was added and the vessel was placed in a shaker for 18 hours at room temperature. After deprotection, the solution was filtered into a centrifuge tube $(10 \mathrm{~mL})$ and distilled water $(2 \mathrm{~mL})$ was added. The ammonium hydroxide was evaporated in vacuo (samples were transferred to microcentrifuge tubes and placed in a SpeedVac) and the remaining solution was purified by HPLC (see below). After purification, the oligonucleotides were desalted with DNase/RNase free $\mathrm{H}_{2} \mathrm{O}$ using Illustra NAP-5 columns (Sephadex G-25 DNA grade, GE Healthcare) according to manufacturer instructions. The desalted oligonucleotides were quantified by UV-Vis $\left(\mathrm{A}_{260}\right.$, using predicted molar extinction coefficients for native dNTPs and $\varepsilon=5,900 \mathrm{M}^{-1} \mathrm{~cm}^{-1}$ for 7-NI at $260 \mathrm{~nm}$ ) and confirmed by LC-MS (see below). The purity was assessed by HPLC reinjection of the purified oligonucleotides (see Supporting Information for chromatograms).

Oligonucleotide 4. Purity $=95.9 \%$ (260 nm). MS calc'd 9502.2, found 9501.6 (parent) Oligonucleotide 5. Purity = 97.9\% (260 nm). MS calc'd 9513.2, found 9513.9 (parent) Oligonucleotide 6. Purity = 95.8\% (260 nm). MS calc'd 9367.1, found 9368.1 (parent) Oligonucleotide 7. Purity $=98.6 \%(260 \mathrm{~nm})$. MS calc'd 9524.2, found 9524.7 (parent) Oligonucleotide 8. Purity = 98.4\% (260 nm). MS calc'd 9232.9, found 9233.1 (parent) Oligonucleotide 9. Purity $=98.5 \%(260 \mathrm{~nm})$. MS calc'd 9551.2, found 9551.7 (parent) Oligonucleotide 10. Purity $=96.1 \%(260 \mathrm{~nm})$. MS calc'd 9114.8, found 9113.5 (parent) Oligonucleotide 11. Purity = 93.0\% $(260 \mathrm{~nm})$. MS calc'd 9502.2, found 9502.0 (parent) Oligonucleotide 12. Purity $=95.3 \%(260 \mathrm{~nm})$. MS calc'd 9551.2, found 9550.8 (parent) Oligonucleotide 13. Purity $=94.5 \%(260 \mathrm{~nm})$. MS calc'd 9486.2, found 9486.4 (parent) Oligonucleotide 14. Purity = 93.0\% $(260 \mathrm{~nm})$. MS calc'd 4557.0, found 4556.8 (parent)

\section{HPLC Purification \& LC-MS Analysis}

Oligonucleotides were HPLC purified on an Agilent 1200 series instrument equipped with a diode array detector and a PLRP-S column $(8 \mu \mathrm{m}, 100 \AA$, $4.6 \times 150 \mathrm{~mm}$, Agilent Technologies). The analysis method $(2.750 \mathrm{~mL} / \mathrm{min}$ flow rate) involved isocratic $100 \mathrm{mM}$ 
TEAA (aqueous, pH 7.0, Sigma-Aldrich; 0 to 5 mins) followed by a linear gradient to $10 \%$ $100 \mathrm{mM}$ TEAA:MeCN (1:1, 5 to 10 mins) and finally a linear gradient of $30 \%$ to $70 \% 100$ mM TEAA:MeCN (1:1, 10 to 45 mins). Wavelengths monitored $=215 \mathrm{~nm}$ and $260 \mathrm{~nm}$. LCMS was performed on an Agilent 1100 series HPLC instrument equipped with an Agilent MSD SL Ion Trap mass spectrometer (operating in negative ion mode). A Zorbax SB-C18 column ( $5 \mu \mathrm{m}, 300 \AA, 0.5 \times 150 \mathrm{~mm}$, Agilent Technologies) was used for LC-MS analysis. The analysis method $\left(15 \mu \mathrm{L} / \mathrm{min}\right.$ flow rate) involved $15 \mathrm{mM}$ aqueous $\mathrm{NH}_{4} \mathrm{OAc}$ containing $2 \% \mathrm{MeCN}$ followed by a linear gradient of $2 \%$ to $25 \% \mathrm{MeCN}$ ( 0 to $15 \mathrm{mins}$ ) and $25 \%$ to $60 \% \mathrm{MeCN}$ (15 to $25 \mathrm{mins}$ ). Wavelengths monitored $=215 \mathrm{~nm}$ and $260 \mathrm{~nm}$.

\section{Thermal Melting Analysis}

Thermal melting analyses were performed on a temperature-controlled Agilent Cary 100 UV-Vis spectrophotometer containing a 6-cell block with a path length of $1 \mathrm{~cm}$. A degassed aqueous solution of $10 \mathrm{mM}$ sodium cacodylate, $10 \mathrm{mM} \mathrm{KCl}, 10 \mathrm{mM} \mathrm{MgCl}_{2}$, and $5 \mathrm{mM}$ $\mathrm{CaCl}_{2}$ (pH 7.0) was used as analysis buffer. ${ }^{32}$ Oligonucleotides $(1 \mathrm{nmol})$ were mixed in the buffer $(1 \mathrm{~mL})$. Before data collection, samples were heated to $90{ }^{\circ} \mathrm{C}$ and cooled to a starting temperature of $30{ }^{\circ} \mathrm{C}$ with a $5{ }^{\circ} \mathrm{C} / \mathrm{min}$ ramp. Data points were recorded at $\lambda=260 \mathrm{~nm}$ every 12 seconds on a $0.5{ }^{\circ} \mathrm{C} / \mathrm{min}$ ramp from $30{ }^{\circ} \mathrm{C}$ to $90{ }^{\circ} \mathrm{C}$. After data collection, the sample was cooled back down to $30{ }^{\circ} \mathrm{C}$ on a $5{ }^{\circ} \mathrm{C} / \mathrm{min}$ ramp. The method was repeated to obtain a technical replicate. The experiment was repeated to obtain a biological replicate ( $\mathrm{n}=4$ total analyses). The reported thermal melting temperatures $\left(\mathrm{T}_{\mathrm{m}}\right)$ were calculated from the maximum of the first derivative of the denaturation curve (Cary WinUV Thermal Application; $\mathrm{v}$ 4.20). Mean $\mathrm{T}_{\mathrm{m}}$ values (with standard deviation) were calculated from the individual $T_{m}$ values obtained from each replicate $(n=4)$.

\section{Photolysis, Exponential Decay, and Quantum Yield Analysis}

DNA photolysis experiments were carried out using a Rayonet photochemical reactor (RMR-600, Southern New England Ultraviolet Co.) fitted with eight, $350 \mathrm{~nm}$ bulbs. To enable quantitative analysis of photochemical decay of DNA decoys, calibration plots for each DNA decoy were generated. Increasing concentrations of each DNA decoy $(0.55,1.65$, $4.94,14.81,44.44,133.33 \mathrm{pmol}$ ) were added to a fixed concentration of a non-modified DNA oligonucleotide (5'-TAACTA-3', $100 \mathrm{pmol}$ ) and analyzed by extracted ion current (EIC) LC-MS (masses monitored at -9 charge state for decoys). ${ }^{33}$ A calibration plot was created by plotting the ratio of decoy:standard area under the curve (AUC) versus DNA decoy concentration, yielding calibration plots with a slope-intercept equation of $R^{2}>0.99$.

Quantitative analysis of DNA decoy photolysis was performed by dissolving the DNA decoy ( 800 pmol) in DNase/RNase free $\mathrm{H}_{2} \mathrm{O}$ and then adding the solution to conical pulled point vial inserts ( $250 \mu \mathrm{L}$; Agilent, 8010-0125). Vessels containing the aqueous DNA solution was placed into the photochemical reactor and irradiated (light intensity: $5.66 \times 10^{-8} \mathrm{ein}^{-2} \mathrm{~s}^{-1}$; calculated as described below). Aliquots $(4 \mu \mathrm{L})$ were taken at several time points $(1,2,5,7$, $10,15,20,25 \mathrm{~min})$, diluted with standard $(1 \mu \mathrm{L})$ and then analyzed by LC-MS. The concentration of the decoy species from irradiation were determined by fitting the decoy/ standard ratios from each sample into the slope-intercept equation from the calibration plot to yield the amount of decoy (pmol) in sample. This process was repeated for each 
prominent molecular ion observed in the photolysis sample. Furthermore, this quantitative analysis method assures comparable ionization properties for the photolyzed products in comparison to the non-irradiated sample. First order decay analysis (GraphPad Prism; v5.0b) was then fitted to the data (percentage of starting material over time) to obtain the decay equation and half-life $\left(\mathrm{t}_{1 / 2}\right)$ of the DNA decoy. Mean $\mathrm{t}_{1 / 2}$ values (with standard deviation) were calculated from the fitting of the decay curve with the individual data points obtained from each replicate $(n=4)$.

Quantum yield $(\Phi)$ calculations were carried out to determine the efficiency of photolysis of CRDD 9 (eq. 1). The intensity of the light source (I, eq. 2) was determined using $\mathrm{K}_{3}\left[\mathrm{Fe}\left(\mathrm{C}_{2} \mathrm{O}_{4}\right)_{3}\right]$ actinometry as previously described. ${ }^{34,35}$ In brief, a solution of $\mathrm{K}_{3}\left[\mathrm{Fe}\left(\mathrm{C}_{2} \mathrm{O}_{4}\right)_{3}\right] 3 \mathrm{H}_{2} \mathrm{O}$ in distilled $\mathrm{H}_{2} \mathrm{O}(6 \mathrm{M}, 2 \mathrm{~mL})$ was irradiated for 180 seconds in the Rayonet equipped with eight, $350 \mathrm{~nm}$ bulbs. After irradiation, the sample was transferred to a volumetric flask $(25 \mathrm{~mL})$. To the flask was added aqueous buffer $(3 \mathrm{~mL}$; recipe to make a $500 \mathrm{~mL}$ solution of aqueous buffer: $300 \mathrm{~mL}$ of $1.0 \mathrm{M} \mathrm{NaOAc}, 180 \mathrm{~mL}$ of $1.0 \mathrm{M} \mathrm{H}_{2} \mathrm{SO}_{4}$, and $20 \mathrm{~mL}$ distilled $\mathrm{H}_{2} \mathrm{O}$ ), phenanthroline solution ( $3 \mathrm{~mL}$ of $0.1 \% \mathrm{v} / \mathrm{v}$ phenanthroline in distilled $\mathrm{H}_{2} \mathrm{O}$ ), KF solution (1 mL of a $2.0 \mathrm{M}$ solution), and distilled water ( $\sim 18 \mathrm{~mL}$, to $25 \mathrm{~mL}$ ). The solution was placed in the dark for 1 hour. A non-irradiated sample was prepared in the same manner. After 1 hour, the solutions were transferred to a cuvette and the $A_{510}$ was measured for both samples. The Rayonet light intensity was then calculated using eq. $2\left(5.66 \times 10^{-8}\right.$ ein $\left.\mathrm{cm}^{-2} \mathrm{~s}^{-1}\right)$. The extinction coefficient at $350 \mathrm{~nm}\left(\varepsilon_{350}\right)$ of CRDD 9 was calculated by UV-Vis absorbance using the Beer-Lambert law $\left(7070 \mathrm{M}^{-1} \mathrm{~cm}^{-1}\right)$. The irradiation time for $90 \%$ conversion $\left(\mathrm{t}_{90 \%}\right)$ of the DNA decoy was calculated from the first order decay equation (above). Quantum yield was then calculated using eq. 1 to give a value less than one. ${ }^{36}$

$$
\Phi=\left(\mathrm{I}^{*} \sigma^{*} t_{90 \%}\right)^{-1} \quad \text { (Eq. 1) }
$$

where $\sigma\left(\mathrm{cm}^{-2} \mathrm{~mol}^{-1}\right)$ is equal to $1000 * \varepsilon_{350}$ of the DNA decoy

$$
\text { I } \quad\left(\text { ein } \quad c m^{-2} \quad \mathrm{~s}^{-1}\right)=\left(\mathrm{V}_{1}{ }^{*} \mathrm{~V}_{3}{ }^{*} \Delta \mathrm{A}_{510}\right) /\left(1000 \quad(m L / 1){ }^{*} \varepsilon_{510}{ }^{*} \mathrm{~V}_{2}{ }^{*} \Phi_{F e}{ }^{*} \mathrm{t}\right)
$$

where $\mathrm{V}_{1}$ is the volume of $\mathrm{K}_{3}\left[\mathrm{Fe}\left(\mathrm{C}_{2} \mathrm{O}_{4}\right)_{3}\right]$ irradiated $(\mathrm{mL}) ; \mathrm{V}_{2}$ is the volume of the $\mathrm{K}_{3}\left[\mathrm{Fe}\left(\mathrm{C}_{2} \mathrm{O}_{4}\right)_{3}\right]$ solution transferred to the volumetric flask $(\mathrm{mL}) ; \mathrm{V}_{3}$ is the volume of the volumetric flask $(\mathrm{mL}) ; \Delta \mathrm{A}_{510}$ is the difference in absorbances at $510 \mathrm{~nm}$ between the irradiated and non-irradiated samples; $\varepsilon_{510}$ is the extinction coefficient of $\mathrm{K}_{3}\left[\mathrm{Fe}\left(\mathrm{C}_{2} \mathrm{O}_{4}\right)_{3}\right]$ at $510 \mathrm{~nm}\left(11,100 \mathrm{~cm}^{-2} \mathrm{~s}^{-1}\right)^{34} ; \Phi_{\mathrm{Fe}}$ is the quantum yield of $\mathrm{K}_{3}\left[\mathrm{Fe}\left(\mathrm{C}_{2} \mathrm{O}_{4}\right)_{3}\right] \bullet 3 \mathrm{H}_{2} \mathrm{O}(1.21)^{34}$; and $\mathrm{t}$ is the time irradiated (s).

\section{P-DNA Radiolabeling}

DNA decoys in DNase/RNase free water were annealed by heating to $95{ }^{\circ} \mathrm{C}$ in a heating block for 5 minutes, followed by slow cooling to room temperature. To a microcentrifuge tube $(1.7 \mathrm{~mL})$ was added the annealed DNA decoy $(50 \mathrm{pmol})$ and T4 polynucleotide kinase (PNK) buffer ( $5 \mu \mathrm{L}$ of a 10X solution, Thermo Scientific). DNase/RNase-free $\mathrm{H}_{2} \mathrm{O}$ was 
added to yield a final volume of $40 \mu \mathrm{L}$. The reaction tube was placed into a shielded rack then $\left[\gamma^{32} \mathrm{P}\right]$-ATP $(5 \mu \mathrm{L} ; 6,000 \mathrm{Ci} / \mathrm{mmol}$, Perkin Elmer $)$ was added. PNK was diluted in DNase/RNase-free $\mathrm{H}_{2} \mathrm{O}(1: 10)$ then added to the reaction $(5 \mu \mathrm{L})$. The reaction was briefly mixed, centrifuged (to remove any material from cap), and then placed in a $37^{\circ} \mathrm{C}$ heat block for 30 minutes. Heating to $70{ }^{\circ} \mathrm{C}$ for 30 minutes in the second heat block was then used to inactivate the kinase. The radioactive reaction mixture was transferred to an Illustra MicroSpin G-50 column (GE Healthcare, prepared according to vendor instructions) and centrifuged at $1500 \mathrm{rpm}$ for 20 seconds to yield ${ }^{32} \mathrm{P}$-labeled oligonucleotides. The radioactivity of the oligonucleotides were quantified (counts/min/ $\mu \mathrm{L}$ ) by transferring an aliquot to an Eppendorf tube followed by analysis on a Beckman LS 6500 multi-purpose scintillation counter (dry counting).

\section{Electrophoretic Mobility Shift Assays}

Binding reactions containing binding buffer $(2 \mu \mathrm{L}$ of a $10 \mathrm{X}$ solution; $10 \mathrm{X}$ solution: $100 \mathrm{mM}$ Tris, $10 \mathrm{mM}$ EDTA, $500 \mathrm{mM} \mathrm{NaCl}$, and 10\% NP-40), ${ }^{37}$ recombinant p50 protein $(0.5 \mu \mathrm{L}$; $0.50 \mu \mathrm{g} / \mu \mathrm{L}$, Enzo Life Sciences, BML-UW9885-0050, amino acids 35-381), recombinant p65 protein $(0.5 \mu \mathrm{L} ; 0.50 \mu \mathrm{g} / \mu \mathrm{L}$ Sino Biological, 12054-H09E, amino acids 1-306), and DNase/RNase free $\mathrm{H}_{2} \mathrm{O}$ (to a final volume of $20 \mu \mathrm{L}$ ) were prepared in microcentrifuge tubes $(0.65 \mathrm{~mL})$ and incubated on ice for 30 mins. ${ }^{32} \mathrm{P}$-labeled DNA decoys $(1 \mu \mathrm{L}, 25,000$ counts $/ \mathrm{min} / \mu \mathrm{L}$ ) were added to the binding reaction and then incubated at $37{ }^{\circ} \mathrm{C}$ for 10 mins.

For supershift experiments, binding reactions containing recombinant p50 proteins $(0.5 \mu \mathrm{L}$; $0.50 \mu \mathrm{g} / \mu \mathrm{L}$, Enzo Life Sciences, BML-UW9885-0050, amino acids 35-381), recombinant p65 protein $(0.5 \mu \mathrm{L} ; 0.50 \mu \mathrm{g} / \mu \mathrm{L}$ Sino Biological, 12054-H09E, amino acids 1-306 [Fig. 3a and Supplementary Fig. 3a] or $2.5 \mu \mathrm{L} ; 0.10 \mu \mathrm{g} / \mu \mathrm{L}$ Active Motif, 31302, amino acids 1-537 [Supplementary Fig. 3b]), p50 antibody $(10 \mu \mathrm{L} ; 200 \mu \mathrm{g} / 0.1 \mathrm{ml}$, Santa Cruz Biotechnology, sc-7178 x), or p65 antibody ( $10 \mu \mathrm{L} ; 200 \mu \mathrm{g} / 0.1 \mathrm{ml}$, Santa Cruz Biotechnology, sc-8008 x) were prepared in microcentrifuge tubes $(0.65 \mathrm{~mL})$ and incubated on ice for $60 \mathrm{mins} .{ }^{32} \mathrm{P}$ labeled DNA decoys $(1 \mu \mathrm{L}, 25,000$ counts $/ \mathrm{min} / \mu \mathrm{L})$ were added to the binding reaction and then incubated at $37^{\circ} \mathrm{C}$ for 10 mins.

For binding constant studies (Fig. 3 and Fig. 4b), the DNA concentration was held constant $(20,000$ counts $/ \mathrm{min} / \mu \mathrm{L})$ and titrated with increasing p50-p65 heterodimer, p50-p50 homodimer, or p65-p65 homodimer at various concentrations $(0,0.90 \mathrm{nM}, 9.00 \mathrm{nM}, 17.98$ nM, $26.98 \mathrm{nM}, 35.97 \mathrm{nM}, 44.96 \mathrm{nM}, 89.92 \mathrm{nM}, 134.88 \mathrm{nM}$, and $179.84 \mathrm{nM} ; 500 \mathrm{nM}$ was only used for decoy 10) similar to that previously described. ${ }^{28}$ Recombinant p50 protein was from Enzo Life Sciences (BML-UW9885-0050, amino acids 35-381) and recombinant p65 protein was from Sino Biological (12054-H09E, amino acids 1-306). The fraction of DNA bound in each reaction was determined by dividing the densitometry of each bound band by the total densitometry of the bound and free bands. These fractions were then plotted on a semi-logarithmic plot (GraphPad Prism; v5.0b) and the equilibrium dissociation constants were calculated. Mean \pm SD. $(n=3)$.

For catch and release, binding reactions were then transferred to glass HPLC vial inserts (each $20 \mu \mathrm{L}$ binding reaction was pipetted into individual inserts) and irradiated (with the exception of non-irradiated control samples) in the Rayonet with eight $350 \mathrm{~nm}$ bulbs 
$\left(5.66 \times 10^{-8} \mathrm{ein}^{-2} \mathrm{~s}^{-1}\right)$ at room temperature. The samples were taken out of the Rayonet at various time points and transferred $(20 \mu \mathrm{L}$ volume) to a new microcentrifuge tube $(0.65$ $\mathrm{mL}$ ). For rebinding studies (Fig. 5a, lane 10), additional ${ }^{32} \mathrm{P}$-labeled DNA was added to only that sample $(1 \mu \mathrm{L}, 25,000$ counts $/ \mathrm{min} / \mu \mathrm{L}$ of DNA). All samples and controls were then incubated at $37^{\circ} \mathrm{C}$ for 2 hours.

For photochemical stability studies, binding reactions containing binding buffer, recombinant p50 protein $(0.5 \mu \mathrm{L} ; 0.50 \mu \mathrm{g} / \mu \mathrm{L}$, Enzo Life Sciences, BML-UW9885-0050, amino acids 35-381), recombinant p65 protein $(0.5 \mu \mathrm{L} ; 0.50 \mu \mathrm{g} / \mu \mathrm{L}$ Sino Biological, $12054-$ $\mathrm{H} 09 \mathrm{E}$, amino acids 1-306), and DNase/RNase free $\mathrm{H}_{2} \mathrm{O}$ (to a final volume of $19 \mu \mathrm{L}$ ) were prepared in microcentrifuge tubes $(0.65 \mathrm{~mL})$ and incubated at room temperature for 10 mins. The sample to be irradiated $(19 \mu \mathrm{L})$ was pipetted into a glass HPLC vial insert and irradiated in the Rayonet with eight $350 \mathrm{~nm}$ bulbs $\left(5.66 \times 10^{-8} \mathrm{ein}^{-2} \mathrm{~s}^{-1}\right)$ at room temperature for 1 $\mathrm{hr}$. The sample was then transferred to a new microcentrifuge tube. ${ }^{32} \mathrm{P}$-labeled DNA decoys $(1 \mu \mathrm{L}, 25,000$ counts $/ \mathrm{min} / \mu \mathrm{L})$ were added to the binding reaction and then incubated at $37^{\circ} \mathrm{C}$ for 10 mins.

For gel analysis, loading dye ( $2 \mu \mathrm{L}, 10 \mathrm{X}$ solution; $0.5 \mathrm{X}$ TBE, $40 \%$ glycerol, $2 \mathrm{mg} / \mathrm{mL}$ Orange $\mathrm{G}$ dye, Sigma) was added to each reaction and samples were loaded onto a 5\% nondenaturing PAGE gel that was pre-run at $200 \mathrm{~V}$ for $1 \mathrm{hr}$ in $0.5 \mathrm{X}$ TBE. Samples were electrophoresed at $200 \mathrm{~V}$ until the loading dye was $\sim 3 / 4$ down the gel. The gel was transferred to filter paper (Bio-Rad; the plates were pried apart and the gel was placed on the wetted filter paper), covered with plastic wrap and cellophane (Bio-Rad), and dried for $1 \mathrm{hr}$ (Gel Air Dryer, Bio-Rad). The gel was transferred to a phosphorimager screen overnight and then analyzed on a Typhoon FLA 7000 biomolecular imager (GE Healthcare). Images were analyzed using ImageQuant TL software (v 7.0, GE Healthcare).

\section{Western Blots}

Binding reactions were prepared as described above for EMSA analysis, except the binding buffer was omitted. Western blots were performed as previously described. ${ }^{38}$ The sample to be irradiated $(20 \mu \mathrm{L})$ was pipetted into a glass HPLC vial insert and irradiated in the Rayonet with eight $350 \mathrm{~nm}$ bulbs $\left(5.66 \times 10^{-8} \mathrm{ein}^{-2} \mathrm{~s}^{-1}\right)$ at room temperature for $1 \mathrm{hr}$. The sample was then transferred to a new microcentrifuge tube. To each sample was added NuPAGE 4X LDS sample buffer (5 $\mu \mathrm{L}$, Invitrogen) and NuPAGE 10X sample reducing agent $\left(2 \mu \mathrm{L}\right.$, Invitrogen) and the samples were heated to $99^{\circ} \mathrm{C}$ for 5 minutes. Protein samples were separated on a gradient 4-12\% SDS-PAGE gel (Invitrogen) using MES SDS running buffer (NuPAGE), and then electrotransferred to a polyvinylidene difluoride membrane (Immobilon). The membrane was transferred to a heat-sealed bag containing Odyssey blocking buffer (5 mL, LI-COR Biotech.) to block the membrane overnight at $4{ }^{\circ} \mathrm{C}$. Proteins were detected by incubation with primary antibodies for p65 (5 $\mu \mathrm{L}$; Santa Cruz Biotechnology, sc-372) and p50 (30 $\mu$ L; Enzo Life Sciences, ALX-804-043-C100) in a heatsealed bag containing blocking buffer $(5 \mathrm{~mL})$ overnight at $4{ }^{\circ} \mathrm{C}$. The membrane was then briefly washed by gentle rocking in $\mathrm{ddH}_{2} \mathrm{O}(50 \mathrm{~mL}, 1 \mathrm{~min}$, total $5 \mathrm{x})$, and then incubated with IRDye 800 anti-rabbit (5 $\mu$ L; LI-COR Biotech., 926-32211) and IRDye 680 anti-mouse (5 $\mu \mathrm{L}$; LI-COR Biotech., 926-68020) conjugated secondary antibodies together in a heat- 
sealed bag containing blocking buffer $(5 \mathrm{~mL})$ for 2 hours at room temperature. The membrane was again washed via gentle rocking in $\mathrm{ddH}_{2} \mathrm{O}(50 \mathrm{~mL}, 1 \mathrm{~min}$, total $5 \mathrm{x})$. The immunocomplexes were visualized using the Odyssey classic infrared imaging system (LICOR Biotech.).

\section{Supplementary Material}

Refer to Web version on PubMed Central for supplementary material.

\section{ACKNOWLEDGMENT}

This work was supported by the University of Minnesota (Academic Health Center, Seed Grant and start-up funds to D.A.H.). N.B.S. acknowledges the American Heart Association (13PRE14640004 and 15PRE22950024) for a pre-doctoral fellowship and the University of Minnesota graduate school for funding. We acknowledge the Analytical Biochemistry Core Facility of the Masonic Cancer Center (University of Minnesota) for mass spectrometry resources, which is supported by the NIH (P30-CA77598).

\section{REFERENCES}

1. Gambari R. New trends in the development of transcription factor Decoy (TFD) pharmacotherapy. Curr. Drug Targets. 2004; 5:419-430. [PubMed: 15216908]

2. Tomita N, Ogihara T, Morishita R. Transcription factors as molecular targets: Molecular mechanisms of decoy ODN and their design. Curr. Drug Targets. 2003; 4:603-608. [PubMed: 14577649]

3. Mann MJ. Transcription factor decoys: A new model for disease intervention. Ann. NY Acad. Sci. 2005; 1058:128-139. [PubMed: 16394132]

4. Morishita R, Sugimoto T, Aoki M, Kida I, Tomita N, Moriguchi A, Maeda K, Sawa Y, Kaneda Y, Higaki J, Ogihara T. In vivo transfection of cis element "decoy" against nuclear factor- $\kappa \mathrm{B}$ binding site prevents myocardial infarction. Nat. Med. 1997; 3:894-899. [PubMed: 9256281]

5. Penolazzi L, Magri E, Lambertini E, Calò G, M. C, Siciliani G, Piva R, Gambari R. Local in vivo administration of a decoy oligonucleotide targeting NF- $\kappa \mathrm{B}$ induces apoptosis of osteoclasts after application of orthodontic forces to rat teeth. Int. J. Mol. Med. 2006; 18:807-811. [PubMed: 17016609]

6. Metelev VG, Kubareva EA, Oretskaya TS. Regulation of activity of transcription factor NF- $\kappa$ B by synthetic oligonucleotides. Biochemistry (Moscow). 2013; 78:867-878. [PubMed: 24228874]

7. Ceo LM, Koh JT. Photocaged DNA provides new levels of transcription control. ChemBioChem. 2012; 13:511-513. [PubMed: 22271631]

8. Xie S, Nie R, Wang J, Li F, Yuan W. Transcription factor decoys for activator protein-1 (AP-1) inhibit oxidative stress-induced proliferation and matrix metalloproteinases in rat cardiac fibroblasts. Transl. Res. 2009; 153:17-23. [PubMed: 19100954]

9. Souissi I, Najjar I, Ah-Koon L, Schischmanoff PO, Lesage D, Le Coquil S, Roger C, Dusanter-Fourt I, Varin-Blank N, Cao A, Metelev V, Baran-Marszak F, Fagard R. A STAT3-decoy oligonucleotide induces cell death in a human colorectal carcinoma cell line by blocking nuclear transfer of STAT3 and STAT3-bound NF- $\kappa$ B. BMC Cell Biol. 2011; 12:14-14. [PubMed: 21486470]

10. Wang J, Cheng H, Li X, Lu W, Wang K, Wen T. Regulation of neural stem cell differentiation by transcription factors HNF4-1 and MAZ-1. Mol Neurobiol. 2013; 47:228-240. [PubMed: 22944911]

11. Brieke C, Rohrbach F, Gottschalk A, Mayer G, Heckel A. Light-controlled tools. Angew. Chem. Int. Ed. Engl. 2012; 51:8446-8476. [PubMed: 22829531]

12. Lee HM, Larson DR, Lawrence DS. Illuminating the chemistry of life: design, synthesis, and applications of "caged" and related photoresponsive compounds. ACS Chem. Biol. 2009; 4:409427. [PubMed: 19298086] 
13. Liu Q, Deiters A. Optochemical control of deoxyoligonucleotide function via a nucleobase-caging approach. Acc. Chem. Res. 2014; 47:45-55. [PubMed: 23981235]

14. Govan JM, Lively MO, Deiters A. Photochemical control of DNA decoy function enables precise regulation of nuclear factor $\kappa$ B activity. J. Am. Chem. Soc. 2011; 133:13176-13182. [PubMed: 21761875]

15. The term 'depurination' is used liberally to denote cleavage of the nucleobase-sugar bond. The 'depurination-competent' monomers used in this study are not technically purines.

16. Lenox HJ, McCoy CP, Sheppard TL. Site-specific generation of deoxyribonolactone lesions in DNA oligonucleotides. Organic Lett. 2001; 3:2415-2418.

17. Trzupek JD, Sheppard TL. Photochemical generation of ribose abasic sites in RNA oligonucleotides. Organic Lett. 2005; 7:1493-1496.

18. Wang Y, Sheppard TL, Tornaletti S, Maeda LS, Hanawalt PC. Transcriptional inhibition by an oxidized abasic site in DNA. Chem. Res. Toxicol. 2006; 19:234-241. [PubMed: 16485899]

19. Kotera M, Bourdat A-G, Defrancq E, Lhomme J. A highly efficient synthesis of oligodeoxyribonucleotides containing the 2 '-deoxyribonolactone lesion. J. Am. Chem. Soc. 1998; 120:11810-11811.

20. Kotera M, Roupioz Y, Defrancq E, Bourdat A-G, Garcia J, Coulombeau C, Lhomme J. The 7nitroindole nucleoside as a photochemical precursor of 2 -deoxyribonolactone: access to DNA fragments containing this oxidative abasic lesion. Chem. Eur. J. 2000; 6:4163-4169. [PubMed: 11128280]

21. Roupioz Y, Lhomme J, Kotera M. Chemistry of the 2-deoxyribonolactone lesion in oligonucleotides: cleavage kinetics and products analysis. J. Am. Chem. Soc. 2002; 124:91299135. [PubMed: 12149017]

22. Loakes D, Brown DM. 5-Nitroindole as an universal base analogue. Nucleic Acids Res. 1994; 22:4039-4043. [PubMed: 7937128]

23. Crey-Desbiolles C, Berthet N, Kotera M, Dumy P. Hybridization properties and enzymatic replication of oligonucleotides containing the photocleavable 7-nitroindole base analog. Nucleic Acids Res. 2005; 33:1532-1543. [PubMed: 15767278]

24. Hayden MS, Ghosh S. NF- $\kappa$ B, the first quarter-century: remarkable progress and outstanding questions. Gene Dev. 2012; 26:203-234. [PubMed: 22302935]

25. Chen FE, Huang DB, Chen YQ, Ghosh G. Crystal structure of p50/p65 heterodimer of transcription factor NF- $\kappa$ B bound to DNA. Nature. 1998; 391:410-413. [PubMed: 9450761]

26. Mergny JL, Lacroix L. Analysis of thermal melting curves. Oligonucleotides. 2003; 13:515-537. [PubMed: 15025917]

27. Sun L, Carpenter G. Epidermal growth factor activation of NF- $\kappa \mathrm{B}$ is mediated through $\mathrm{I} \kappa \mathrm{B} a$ degradation and intracellular free calcium. Oncogene. 1998; 16:2095-2102. [PubMed: 9572490]

28. Phelps CB, Sengchanthalangsy LL, Malek S, Ghosh G. Mechanism of $\kappa B$ DNA binding by Rel/NF- $\kappa$ B dimers. J. Biol. Chem. 2000; 275:24392-24399. [PubMed: 10825175]

29. Lusic H, Young DD, Lively MO, Deiters A. Photochemical DNA activation. Organic Lett. 2007; 9:1903-1906.

30. Caruthers MH. Chemical synthesis of DNA and DNA analoguesa. Acc. Chem. Res. 1991; 24:278284.

31. Heckel A. Nucleobase-caged phosphoramidites for oligonucleotide synthesis. Curr. Protoc. Nucleic Acid Chem. 2007:1.17.1-1.17.26.

32. Chenoweth DM, Harki DA, Phillips JW, Dose C, Dervan PB. Cyclic pyrrole-imidazole polyamides targeted to the androgen response element. J. Am. Chem. Soc. 2009; 131:7182-7188. [PubMed: 19413319]

33. Yang B, Chang Y, Weyers AM, Sterner E, Linhardt RJ. Disaccharide analysis of glycosaminoglycan mixtures by ultra-high-performance liquid chromatography-mass spectrometry. J. Chromatogr. 2012; 1225:91-98.

34. Kuhn HJ, Braslavsky SE, Schmidt R. Chemical actinometry. Pure Appl. Chem. 2004; 76:21052146. 
35. Demas JN, Bowman WD, Zalewski EF, Velapoldi RA. Determination of the quantum yield of the ferrioxalate actinometer with electrically calibrated radiometers. J. Phys. Chem. 1981; 85:27662771.

36. Zhu Y, Pavlos CM, Toscano JP, Dore TM. 8-Bromo-7-hydroxyquinoline as a photoremovable protecting group for physiological use: Mechanism and scope. J. Am. Chem. Soc. 2006; 128:4267-4276. [PubMed: 16569001]

37. Chenoweth DM, Poposki JA, Marques MA, Dervan PB. Programmable oligomers targeting 5'GGGG-3' in the minor groove of DNA and NF- $\kappa$ B binding inhibition. Bioorg. Med. Chem. 2007; 15:759-770. [PubMed: 17095230]

38. Hexum JK, Tello-Aburto R, Struntz NB, Harned AM, Harki DA. Bicyclic cyclohexenones as inhibitors of NF- $\kappa B$ signaling. ACS Med. Chem. Lett. 2012; 3:459-464. [PubMed: 22866208] 
a.

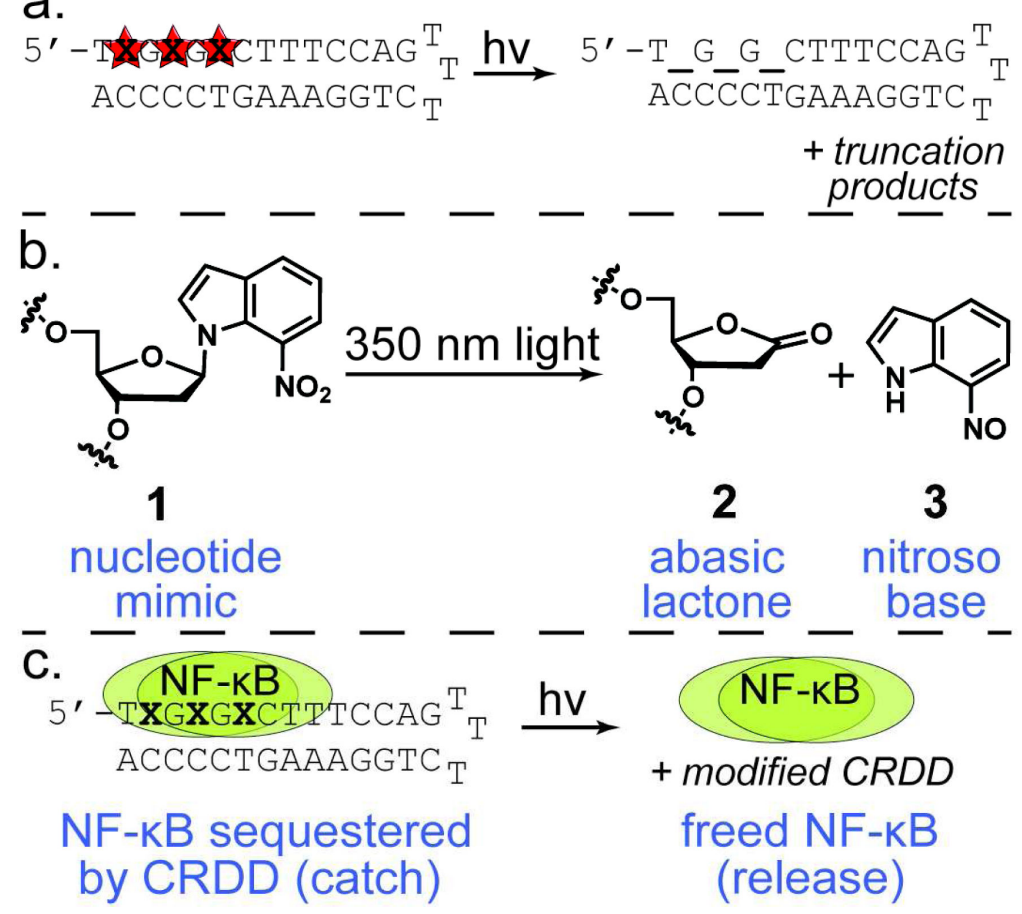

Fig. 1.

A Catch and Release DNA Decoy (CRDD) targeting NF- $\kappa$ B transcription factors. (a) Photolysis of DNA decoys containing photo-responsive nucleotides ( $\mathbf{X}$ with stars) with UVlight $(\mathrm{h} v)$ results in formation of abasic sites (_) and strand cleavage products. (b) 7Nitroindole-containing nucleotides (1) depurinate with UV-light resulting information of 2'deoxyribolactone 2 and 7-nitrosoindole (3) products. (c) Incorporation of three 7-nitroindole nucleotides $(\mathbf{X}=\mathbf{1})$ into a DNA decoy sequence known to target NF- $\kappa \mathrm{B}$ proteins still permit protein binding (catch). Photolysis of the decoy with UV-light $(350 \mathrm{~nm})$ results in the formation of multiple abasic sites and truncation products that have lowered affinity for the protein, thereby enabling dissociation of the NF- $\mathrm{kB}$-CRDD complex (release). 


$$
\begin{aligned}
& \text { a. }
\end{aligned}
$$

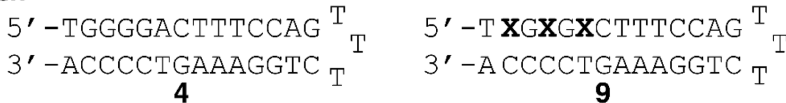

$$
\begin{aligned}
& 5^{\prime}-\text { TGGXGACTTTCCAG }^{\mathrm{T}} \text { T } \text { 5 }^{\prime}-\mathrm{T} \text { _G_G_CTTTCCAG }{ }^{\mathrm{T}} \mathrm{T}
\end{aligned}
$$

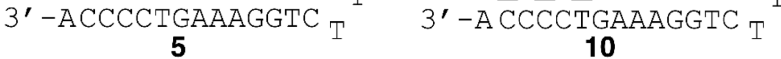

$$
\begin{aligned}
& 5^{\prime} \text {-TGG_GACTTTCCAG }{ }^{\mathrm{T}}{ }_{\mathrm{T}} \text { 5 }^{\prime} \text {-TTGCCGTACCTGAC }{ }^{\mathrm{T}} \mathrm{T}_{\mathrm{T}} \\
& 3^{\prime}-\text { ACC CCAAAGGTC }_{\mathbf{6}} \text { 3 }^{\prime} \text {-AACGGCATGGACTG }{ }_{\mathbf{1 1}} \\
& 5^{\prime}-\mathrm{TG} \mathbf{x G \mathbf { X A C T T T C C A G }}{ }^{\mathrm{T}} \mathrm{T} \quad 5^{\prime}-\mathrm{TT} \mathbf{x} \mathrm{CCXT}_{\mathbf{X}} \mathrm{XCTGAC}^{\mathrm{T}} \\
& \begin{array}{cc}
3^{\prime}-\text { ACCCTGAAAGGTC }_{\mathrm{T}} & 3^{\prime} \text {-AACGGCATGGACTG } \mathrm{T} \\
\mathbf{7} & \mathbf{1 2}
\end{array} \\
& \text { 5'-TG_G_ACTTTCCAG }{ }^{\mathrm{T}}{ }_{\mathrm{T}} \text { 5' }^{\prime} \text {-TAGAGGCTTTCCAG }{ }^{\mathrm{T}}{ }_{\mathrm{T}} \\
& 3^{\prime}-\text { ACC }^{-} \bar{C} \text { TGAAAGGTC } T \quad 3^{\prime} \text {-ACCCCTGAAAGGTC }{ }_{T} \\
& \overline{\mathrm{b}} \text {. }--^{8}-----13-- \\
& \begin{array}{lllllll}
\hline \text { DNA } \quad \mathrm{T}_{\mathrm{m}} /{ }^{\circ} \mathrm{C} & \Delta \mathrm{T}_{\mathrm{m}} /{ }^{\circ} \mathrm{C} & & \text { DNA } & \mathrm{T}_{\mathrm{m}} /{ }^{\circ} \mathrm{C} & \Delta \mathrm{T}_{\mathrm{m}} /{ }^{\circ} \mathrm{C} \\
\hline & 82.6( \pm 0.4) & - & & 70.4( \pm 0.4) & -12.2( \pm 0.6)
\end{array} \\
& 578.5( \pm 0.5) \quad-4.1( \pm 0.7) \quad 10 \quad 66.8( \pm 2.2) \quad-15.8( \pm 2.2) \\
& 681.1( \pm 0.1) \quad-1.5( \pm 0.4) \quad 1185.1( \pm 0.1) \quad- \\
& 7 \quad 72.3( \pm 0.4) \quad-10.3( \pm 0.6) \quad 1272.7( \pm 0.5) \quad-9.9( \pm 0.5) \\
& 870.3( \pm 0.8)-12.3( \pm 0.9) \quad 13 \quad 72.2( \pm 0.3) \quad-10.4( \pm 0.3)
\end{aligned}
$$

Fig. 2.

Thermal stability of synthesized NF- $\kappa$ B-directed (4-10), scramble (11 and 12), and three base pair mismatch (13) DNA decoys. (a) Synthesized decoys 4-13 (X=1; _ = 2). (b) Thermal melting of 4-13 demonstrating DNA duplex destabilization resulting from incorporation of 7-nitroindoles (CRDDs 5, 7, 9, and 12) and more predominantly, abasic sites (CRDDs $\mathbf{8}$ and 10). Thermal melting of $\mathbf{1 3}$ demonstrates destabilization due to three base-pair mismatches. Thermal melting experiments were performed in $10 \mathrm{mM}$ sodium cacodylate, $10 \mathrm{mM} \mathrm{KCl}, 10 \mathrm{mM} \mathrm{MgCl} 2,5 \mathrm{mM} \mathrm{CaCl}_{2}$, $\mathrm{pH} 7.0$ buffer. $\Delta \mathrm{T}_{\mathrm{m}}$ values are relative to 4 . Mean $\pm \operatorname{SD}(n=4)$. 


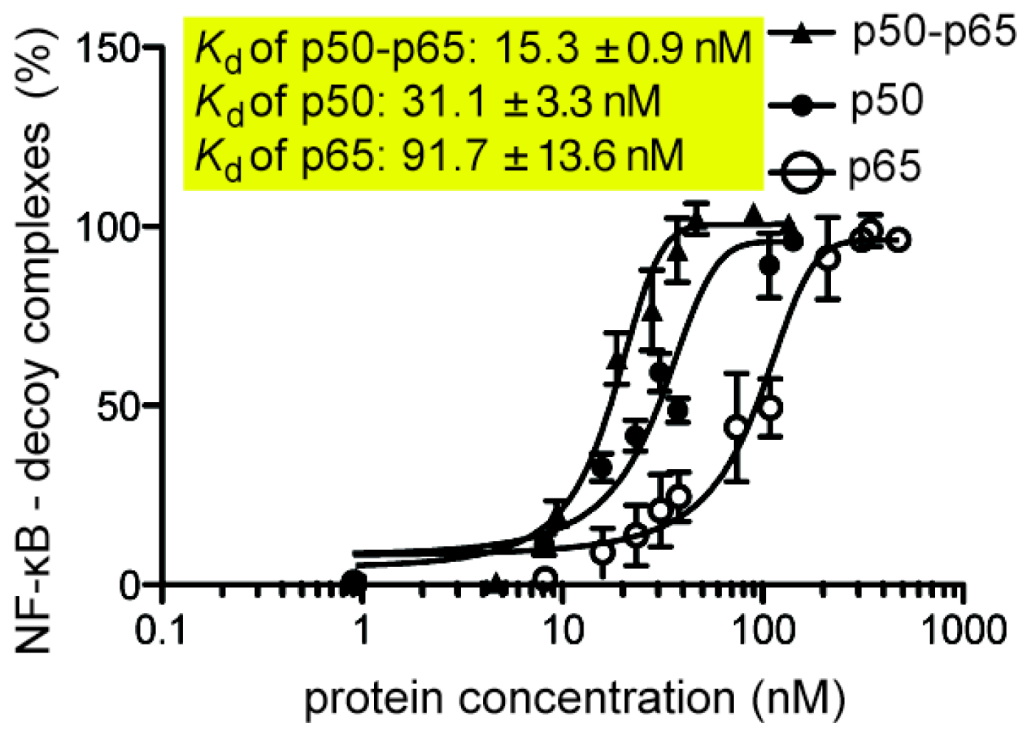

Fig. 3.

Quantitative EMSA analysis to measure equilibrium dissociation $\left(K_{\mathrm{d}}\right)$ constants for $\mathbf{4}$ with p50-p65 heterodimer and p50 and p65 homodimer proteins. Recombinant p50 (35-381) and p65 (1-306) proteins were used in this study. Mean $\pm \mathrm{SD}(\mathrm{n}=3)$. 
a.
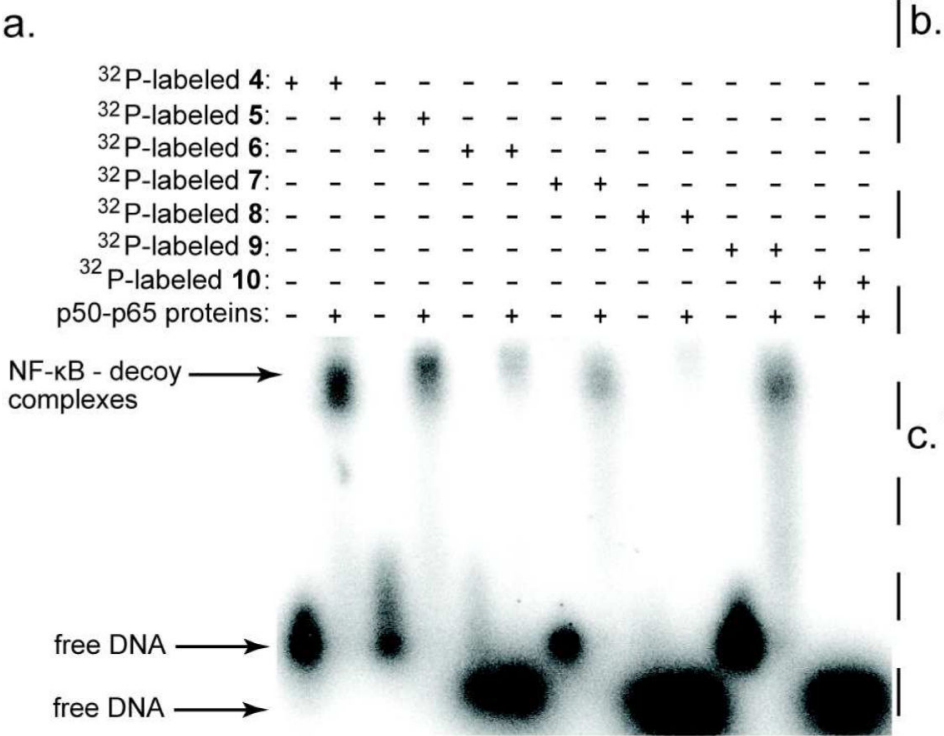

$\overline{\mathrm{d}}$.

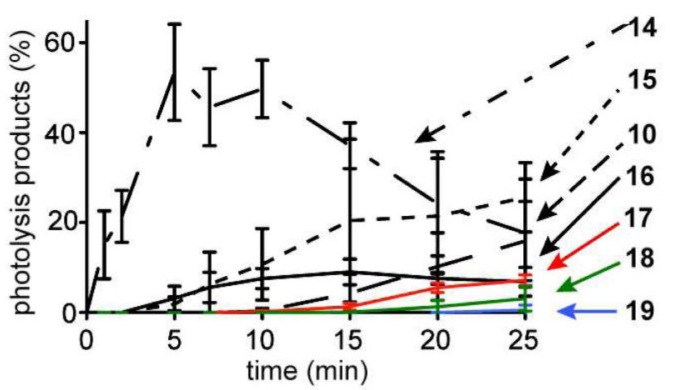

b.

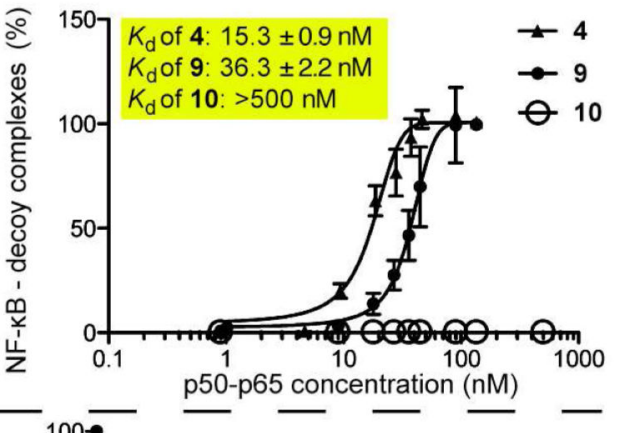

Fig. 4.

(a) Electrophoretic mobility shift assays with 4-10. 5'-32 P-labeled 4-10 incubated with p50 (35-381) and p65 (1-306) recombinant proteins displays formation of the NF- $\mathrm{kB}-\mathrm{CRDD}$ complexes. NF- $\mathrm{kB}$ binding is observed until three abasic sites are formed (i.e., 10).

Scrambled decoys 11 and $\mathbf{1 2}$ and mismatch decoy 13 demonstrate no observable complex formation (Supplemental Figure 2). (b) Quantitative EMSA analysis to measure equilibrium dissociation $\left(K_{\mathrm{d}}\right)$ constants for 4, 9, and 10 with recombinant p50 (35-381) and p65 (1-306) proteins. (c-d) Photolysis of CRDD 9 (350 nm light). Samples analyzed by ionextracted LC-MS. (c) Photolytic decay curve of 9 with calculated half-life and quantum yield $\left(R^{2}=0.97\right)$. (d) Formation of abasic sites and truncation products 10 and 14-19 resulting from photolysis of $\mathbf{9}(\mathbf{P}=5$ ' -phosphate). Dashed line denotes full-length DNA decoys containing abasic products and solid lines denote truncation products (some contain abasic sites as well). Isomers denote constitution isomers resulting from photolysis of $\mathbf{9}$ (e.g., $\mathbf{X}$ and _ are in different arrangements). Mean \pm SD $(n=4)$. An LC-MS chromatogram of the photo-products from irradiation of $\mathbf{9}$ can be found in Supplementary Figure 4. 
a.

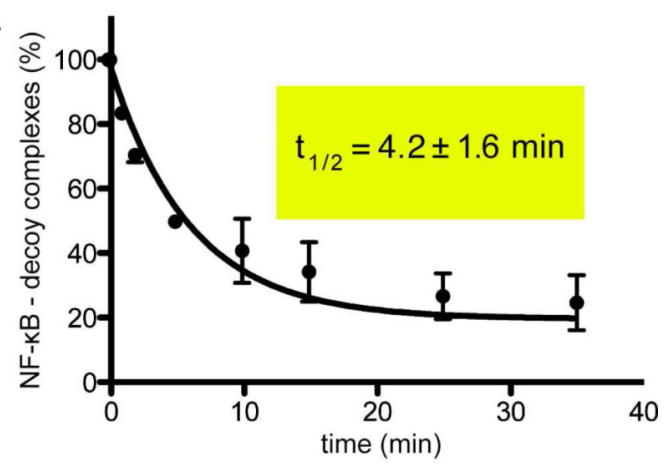

Fig. 5.

Quantitative electrophoretic mobility shift assay with CRDD 9. (a) 5'-32 P-labeled 9 incubated with p50 (35-381) and p65 (1-306) recombinant proteins yields complex formation (catch, $\mathrm{t}=0 \mathrm{~min}$ ), which is dissociated upon photolysis with $350 \mathrm{~nm}$ light (release) in a time-dependent manner. Recovery of the NF- $\kappa$ B-9 complex can be obtained by addition of ${ }^{32} \mathrm{P}$-labeled 9 . (b) Densitometry of EMSAs yielding half-life of $\mathrm{NF}-\kappa \mathrm{B}$ release $\left(\mathrm{R}^{2}=0.93\right)$. Mean \pm SD. $(\mathrm{n}=3)$. 